\title{
História Oral e as festas do Rosário: memória, ancestralidade e identidade negra em Minas Gerais ${ }^{1}$
}

\section{Oral History and the Rosary feasts: memory, ancestry and black identity in Minas Gerais}

\author{
Livia Nascimento Monteiro ${ }^{2}$ \\ lnascimentomonteiro@gmail.com
}

\section{Resumo}

$\mathrm{O}$ artigo procura reconstituir aspectos da festa da Congada e Moçambique de Piedade do Rio Grande - Minas Gerais, a partir das entrevistas orais realizadas com membros de diferentes gerações de congadeiros e moçambiqueiros. Reconhecida como festa do povo negro em devoção a Nossa Senhora do Rosário, Nossa Senhora das Mercês e São Benedito, a festa do Rosário de Piedade do Rio Grande rememora a escravidão e a Abolição, em seus cantos, ritmos e rituais, desde a década de 1920 até o tempo presente. A abordagem histórica desse artigo procurará demonstrar os atores políticos coletivos envolvidos na festa, a relação com a ancestralidade negra, a memória de antepassados escravos e a valorização da identidade negra em Minas Gerais.

Palavras-chaves: história oral, festa do Rosário, identidade negra.

\begin{abstract}
The purpose of this article is to reconstruct aspects of the Congada and Mozambique feast, from Piedade do Rio Grande city, Minas Gerais, based on oral interviews carried out with members from different generations of congadeiros and mosambiqueiros. Recognized as a feast of black people in devotion to Our Lady of the Rosary, Our Lady of Mercy and Saint Benedict, the Rosary feast at Piedade do Rio Grande city remembers slavery and abolition in their songs, rhythms and rituals, from the 1920s to the present time. The historical approach of this article will seek to demonstrate the collective political actors involved in the feast, the relationship with black ancestry, the memory of slaves ancestors and the appreciation of black identity in the present time, embedded in the oral narratives, feasts and family networks of these agents.
\end{abstract}

Keywords: Oral History, Rosary feasts, black identity.

1 Uma versão inicial desse artigo foi discutida no Simpósio Temático "História Oral e Memória das Artes, da Cultura e da Criatividade", no XII Encontro Nacional de História Oral: Política, Ética e Conhecimento, realizado em Teresina-PI, em maio de 2014. Agradeço pelas valiosas contribuições de Márcia Ramos de Oliveira e Ricardo Santhiago.

2 Doutoranda em História na Universidade Federal Fluminense (UFF). Bolsista CNPq. 


\section{Artigos}

O ano era $1873 . \mathrm{Na}$ ermida da fazenda da Vargem, foi batizado José Venâncio Lima, filho de José Venâncio e Perpétua, ambos escravos nessa fazenda. José Venâncio passou boa parte de sua vida nas terras dessa fazenda. Foi casado com Maria José de Faria, filha dos escravos Maria Iria e Militino, ambos escravos da fazenda do Tejuco, próxima à fazenda da Vargem. Nas palavras contadas pelas filhas do casal José Venâncio e Maria José, em 2012, seus pais "pegaram a escravidão, mas meu pai nasceu ventre-livre"3.

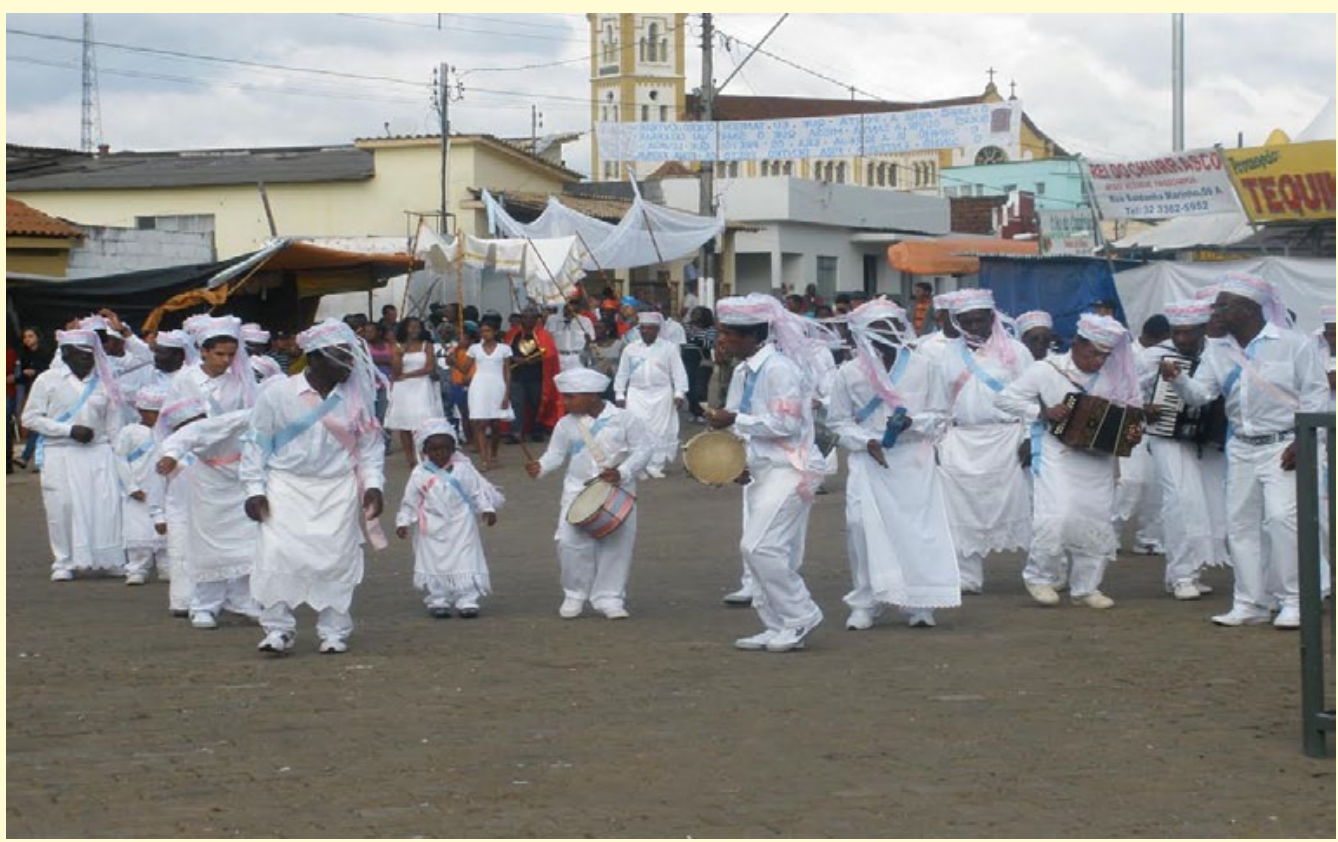

Foto 1: Terno de Congada de Piedade do Rio Grande - MG, maio de 2011. Foto: Lívia N Monteiro

A memória da escravidão dessa família é também transpassada nos rituais, cantos e danças dos ternos de Congada e Moçambique, que José Venâncio ajudou a fundar e foi o primeiro capitão na década de 1920.

Além de José Venâncio, outros vinte e nove homens assinaram a ata de fundação da Associação de Congada e Moçambique de Piedade do Rio Grande, Minas Gerais, datada de 1928. Em comum, todos eram descendentes de escravos e com o fim da escravidão, mantiveram-se nas áreas próximas às fazendas, trabalhando no sistema de parceria com os proprietários, quase sempre, filhos e descendentes dos antigos proprietários das fazendas onde seus pais tinham sido escravos.

Foi através da família de José Venâncio Lima e outras de descendentes de escravos que a Congada e Moçambique de Piedade foi fundada. Foram eles que reinventaram formas de dominação e dependência nas relações com os fazendeiros - elite, majoritariamente branca, da região. A experiência do cativeiro foi requalificada nas primeiras décadas do século XX, o que para Hebe Mattos e Ana Rios significou em relações de trabalho e hierarquias baseadas nas relações escravistas (MATTOS, 2013).

Desvendar as relações familiares das gerações de congadeiros e moçambiqueiros de Piedade tem sido possível por meio dos depoimentos orais colhidos com membros atuais do grupo de Congada e Moçambique. É através dessa fonte que consigo recuperar e recriar, por intermédio da memória dos informantes, os membros da geração do cativeiro, ou seja, os antepassados dos congadeiros e moçambiqueiros, escravizados no século XIX e suas redes familiares, presentes até os dias atuais nas festas do Rosário.

Nesse sentido, a possibilidade de perceber as mudanças e as continuidades nas práticas culturais e familiares das gerações do cativeiro e da liberdade, somente está sendo possível com a análise dos relatos orais. Foi possível perceber, a partir da realização das entrevistas e de suas análi-

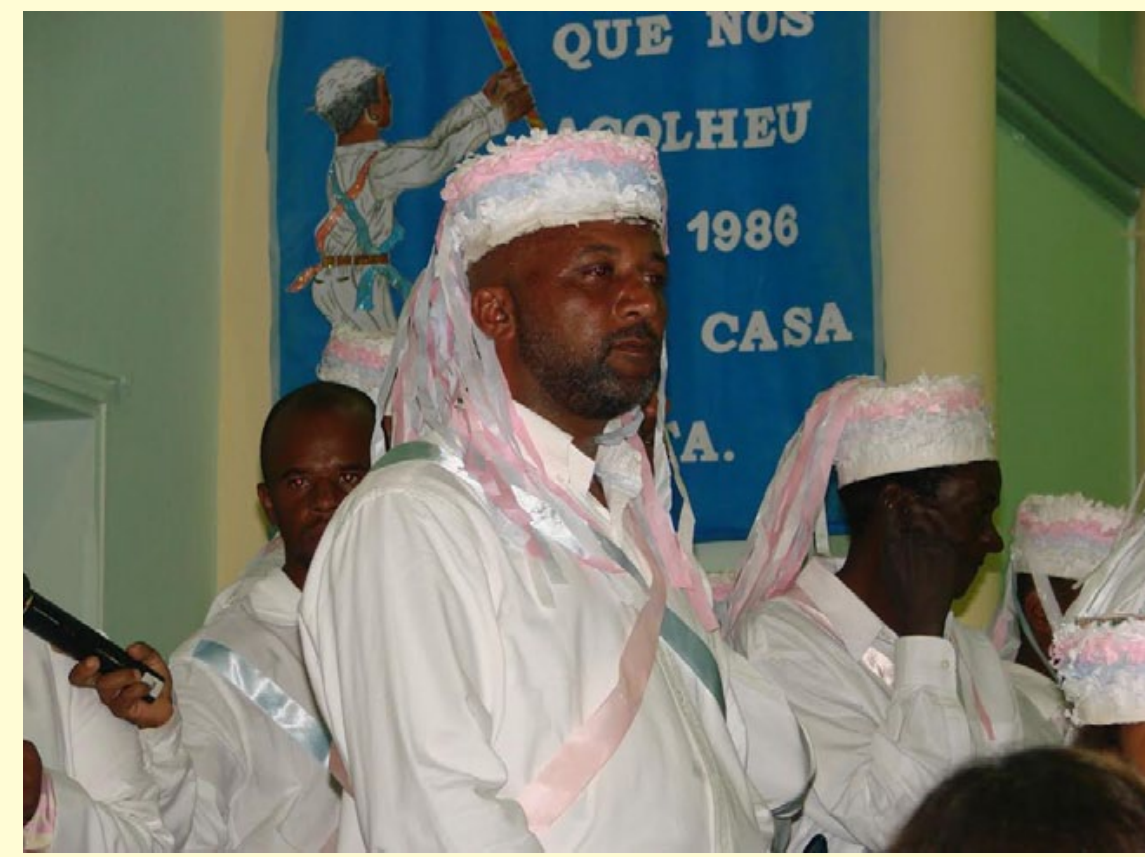

Foto 2: Congadeiro Geraldo Eustáquio Teodoro, maio de 2008. In Memoriam.

3 Entrevista concedida por Maria Emerenciana Silva, Adalgisa Lima e Lourdes Lima Neves dos Santos em 28 de maio de 2012. 
ses, que a História Oral é capaz apenas de suscitar, jamais solucionar os questionamentos, como apresenta Marieta de Moraes Ferreira; a História Oral permite a formulação das perguntas, porém, ela não oferece as respostas e o testemunho oral representa o núcleo da investigação, nunca sua parte acessória (FERREIRA, 2011). Desse modo, o fio condutor, portanto, são as narrativas e as memórias desse grupo, suas formas inventadas, ressignificadas e também silenciadas ao longo do século XX.

Este artigo aborda historicamente a construção das memórias e narrativas dos congadeiros e moçambiqueiros de Piedade do Rio Grande-MG. Esses atores políticos coletivos produzem, a partir das festas do Rosário e da memória de antepassados escravos, a valorização da identidade negra no tempo presente.

A História Oral enquanto método de pesquisa tem proporcionado o resgate da memória em torno das diversas manifestações culturais negras no país. Nesse sentido, analiso, através dos depoimentos orais das três gerações de congadeiros e moçambiqueiros, imbricados com as festas e suas redes familiares, a memória da escravidão e da abolição produzida no pós-Abolição em Minas Gerais, entendido em sua longa duração.

A utilização das fontes orais tem permitido trazer à tona as histórias do grupo em questão e, mais que isso, a agência dos diversos homens e mulheres negros (as) congadeiros (as) e moçambiqueiros (as). As palavras abaixo foram contadas por dona Efigênia do Nascimento Silva, aos 75 anos de idade, logo após o último dia da "festa de maio" de 2013. Dona Efigênia foi cozinheira dessa festa por mais de vinte anos e nas duas horas de entrevista, contou sobre sua experiência de vida marcada por luta e fé.

\begin{abstract}
N. S. do Rosário tem essa festa por causa dos negros, quando a N. Senhora apareceu lá na gruta, na água, juntou os fazendeiros com tudo que é riqueza e foi lá na gruta tirar ela do buraco pra trazer pra Igreja (...) aí trouxeram, mas ela voltou. Então, vou te contar como começou a congada, não acharam ela dentro da Igreja, ela fugiu de noite e foi embora lá para a gruta dela onde apareceu, aí ela ficou lá e quando foi de noite, os negros se juntaram, vestiram tudo de branco, tudo enfeitado, os negros foram lá na gruta onde ela estava, chegou lá e cantaram 'Senhora do Rosário vamos simbora, Oh Senhora do Rosário vamos simbora, a sua casa é sua morada, senhor rei mandou chamar, a sua casa é sua morada', aí N. S. do Rosário 'luiu' eles. ${ }^{4}$
\end{abstract}

Dona Efigênia do Nascimento refere-se ao mito da aparição de Nossa Senhora do Rosário, considerado a narrativa fundadora dos ternos de Moçambique. Para Leda Maria Martins, a descrição narrada é a situação de repressão vivida pelo escravo, uma vez que a princípio o senhor branco não permite que ele cultue a santa, havendo num segundo momento, uma reversão simbólica dessa situação com a retirada da santa das águas pela força do som dos tambores, o que então funda outro poder, que agrupa a comunidade em torno do reinado. Esse mito fundador organiza as relações entre os próprios negros, oriundos de diferentes etnias, e entre estes e os senhores. (MARTINS, 1997).

Para Marina de Mello e Souza, o culto a Nossa Senhora do Rosário permitiu que os escravos e seus descendentes entrassem em contato direto com o saber dos ancestrais, num exemplo de compreensão eminentemente africana de uma simbologia católica (SOUZA, 2002).

A escravidão lembrada pela congada, para Patrícia Costa, "promove a reconciliação com esse passado traumático, na medida em que diversos ternos atualizam durante os festejos a aparição de N. Sra. do Rosário para os cativos, evento transformador da imagem e do valor do escravo perante os senhores" (COSTA, 2006). Ainda para a antropóloga que analisou a Congada de Serra do Salitre, oeste de Minas Gerais, o louvor à N. Sra. do Rosário se constitui chave que permitiu acessar os elementos positivos do passado lembrado por meio da congada.

É interessante perceber o quanto a narrativa da congadeira Efigênia coloca a figura dos negros como central para a retirada da imagem das águas e mantenedor das festas do Rosário, algo em comum em diversos reinados. Ademais, o que torna essa narrativa ainda mais especial é o seguinte trecho: "Porque N. S. do Rosário apareceu lá na gruta, então apareceu um 'monte' de gente rica, juntou e foi tirar ela da gruta pra trazer para a Igrejïnha do Rosário" " . A Igrejinha do Rosário, citada por dona Efigênia, é uma Igreja da cidade onde são realizados os principais rituais nos dias da festa. Esse mito, que é contado e recontado por diversos ternos, foi apropriado por dona Efigênia para as questões locais.

4 Entrevista concedida por Efigênia do Nascimento Silva em 03 de junho de 2013.

5 Entrevista concedida por Efigênia do Nascimento Silva em 03 de junho de 2013. 
A festa em homenagem a Nossa Senhora do Rosário organizada pela Sociedade de Congada e Moçambique de Piedade do Rio Grande, pequena cidade localizada nos campos das vertentes com proxi-

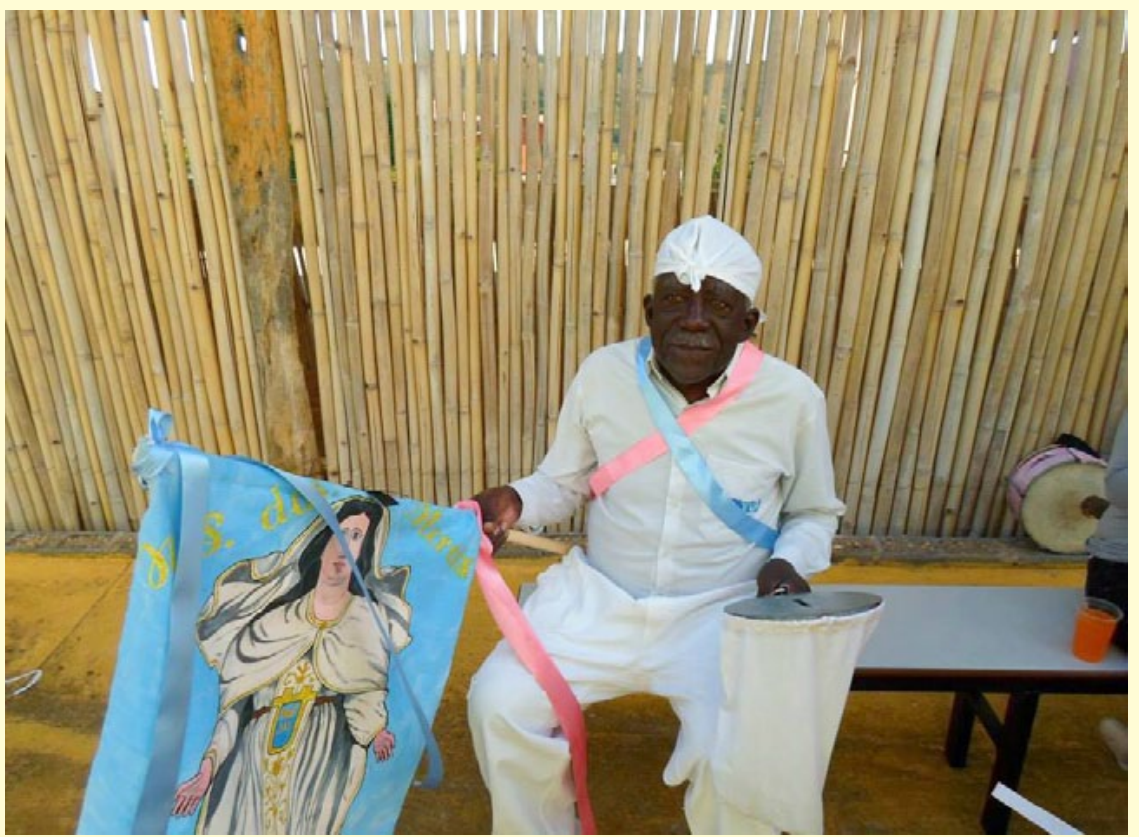

Foto 4: Sr. José Luiz, mais velho moçambiqueiro de Piedade, maio de 2014.

Foto: Rui Ernani. Existem as festividades do Reinado, estrutura mais ampla e complexa que abrange as guardas, os ternos e contempla vários rituais de devoção e festa - e a congada, além de se referir à festa, também dá nome às guardas do Congo.

Em sua análise sobre a Irmandade de Nossa Senhora do Rosário da região de Jatobá, em Belo Horizonte, Leda Maria Martins afirma que as culturas negras que matizaram os territórios americanos, em sua formulação, evidenciaram o cruzamento das tradições e memórias orais africanas com todos os outros códigos e sistemas simbólicos com que se confrontaram. As congadas são as festas e as cerimônias que o Reinado de Nossa Senhora do Rosário fazem para os santos católicos, festejados africanamente (MARTINS, 1997).

Elizabeth Kiddy estudou a Congada da cidade de Oliveira, região central de Minas Gerais. Seu recorte temporal perpassa três diferentes períodos: colonial, imperial e o século XX e sua análise afirma que a resistência, alternada de conformismo, é uma estratégia e uma condição para a manutenção dessa manifestação cultural ao longo dos tempos. Na visão da autora, a congada é uma tradição de heterogenia, pois "projeta-se nas acomodações das práticas ritualísticas uma força espiritual, baseada nos preto-véios e ancestrais, expressa na devoção à santa” (KIDDY, 2005).

De acordo com Marina de Mello e Souza, a coroação dos reis negros no período colonial e imperial ocorria com a eleição dos reis, festividades com danças e as festas promoviam a recriação dos laços comunitários destituídos pelo tráfico (SOUZA, 2002). A historiadora ainda afirma que o momento das eleições representava o processo de recriação de tradições onde mesclavam fragmentos de uma memória africana e elementos da cultura católica portuguesa. A coroação e a realeza representam dentro das irmandades a constituição de identidades africanas, pois há a recuperação dos traços das identidades tribais e dos laços e linhagem,

a união de diversos grupos familiares em torno de um rei, eleito pela comunidade, reforçava o sentido de pertencimento a um grupo e, no quadro da diáspora africana, a recriação destas tradições funcionou como uma forma de sobrepujar a desagregação social promovida pelo tráfico atlântico (SOUZA, 2002).

No terno da Congada e no terno de Moçambique, que são compostas pelos mesmos homens e que juntos compõem a Sociedade de Congada e Moçambique de Piedade do Rio Grande-MG, a rede de relações mantida entre os membros está nos laços de parentesco, compadrio e solidariedade entre tais. Sob a chefia do capitão, do rei e da rainha Conga, todos os homens dançam e cantam em devoção a Nossa Senhora do 
Rosário, Nossa Senhora das Mercês e São Benedito.

Durante os três dias da festa de maio, o terno da Congada apresenta-se durante o sábado até a coroação de N. S. das Mercês, realizada à noite, após a missa e o tom da dança é marcado pelo som da sanfona e os passos pela leveza e alegria. O terno de Moçambique apresenta-se na sexta e no sábado à noite e domingo o dia todo e dançam ao som do tambor com passos firmes e guerreiros. Além dos homens "dançarinos", existe a Corte, formada pela Rainha Conga, eleita entre os membros da Sociedade, o Rei, príncipe e princesas. Pela hierarquia dos

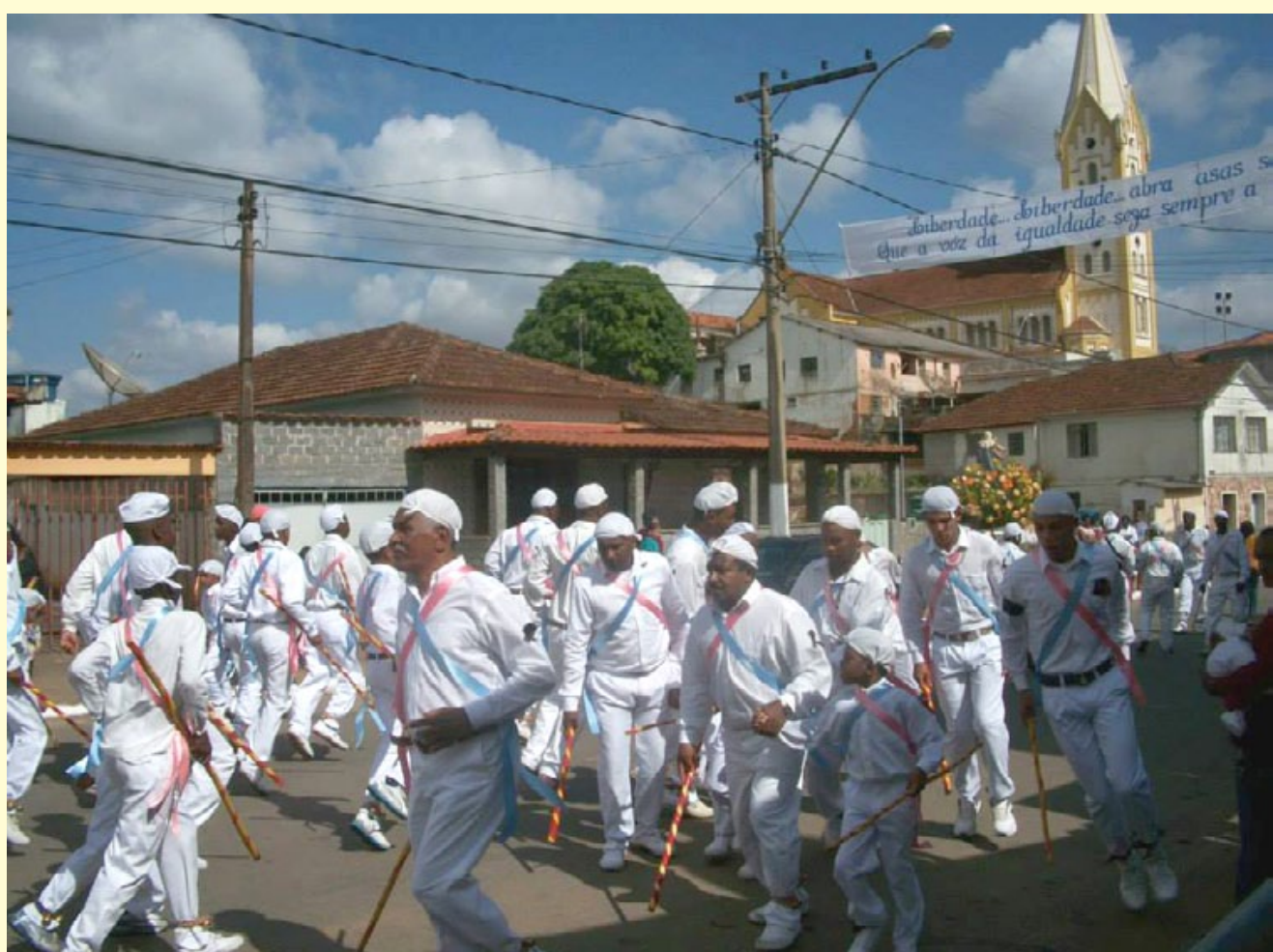

Foto 3: Terno de Moçambique de Piedade do Rio Grande- MG, maio de 2014. Foto: Rui Ernani.

ternos o posto mais alto é ocupado pelo capitão. Durante a festa, acontece a "chamada de reis", que são as promessas pagas em dinheiro pelos príncipes e princesas de promessas, que a cada ano se renova entre os moradores locais.

As três gerações (SIRINELLI, 2006) de congadeiros e moçambiqueiros são, respectivamente: a primeira, que são os fundadores do grupo na década de 1920, todos descendentes de escravos, já falecidos; a segunda, filhos e sobrinhos da primeira geração, marcados pelo fenômeno da migração de Piedade para outras cidades e para o reencontro nas festas anuais e a terceira geração, atual e responsável pela transformação em festa turística e possível registro como patrimônio imaterial do estado de Minas Gerais.

Ao longo do século XX, os membros das três gerações a Congada e o Moçambique de Piedade reinventaram seus ritmos, suas danças e celebrações e suas festas mesclaram práticas como procissões, cerimônia de coroação dos reis, rainhas e princesas, banquetes e várias representações dramáticas.

Em se tratando dos banquetes das "festas de maio", Dona Efigênia Nascimento tem muita experiência. Esteve à frente do grupo de mulheres cozinheiras da festa por anos e na sua narrativa, conta que "tirou esmola" durante todo esse tempo. As esmolas são os donativos doados para a festa, por toda a comunidade. Dona Efigênia se recorda de bater de porta em porta atrás de qualquer doação: "mantimentos, dinheiro, qualquer coisa"'.

Um ponto fundamental dos festejos são as músicas; essas são cantadas pelos congadeiros e moçambiqueiros, que alternam palavras africanas e em português cifrado e muitos de seus significados não são facilmente entendidos, o que promove uma construção identitária entre o próprio grupo, criando elementos de coesão. Os cantos e os versos são do tipo "chamado-resposta", no qual o capitão canta algum ponto e o restante do grupo responde. Segundo Robert Slenes, esse tipo de canto nos momentos de trabalho ou diversão representam um traço típico das canções centro-africanas da região do antigo reino do Congo e diversos temas eram cantadas na região de Congo e Angola, no início do século XX, como desafios entre as lideranças locais (SLENES, 2007).

O canto de Moçambique, entoado pelo capitão e respondido por todos os moçambiqueiros afirma: "Nossa Senhora do Rosário, ela não falava, no dia 13 de maio ela deu sua palavra."”

Ao redor do andor que leva a imagem de N. S. do Rosário, todos os moçambiqueiros cantam e dançam

6 Entrevista concedida por Efigênia do Nascimento Silva em 3 de junho de 2013.

7 Canto de Moçambique de Piedade do Rio Grande-MG. 


\section{Artigos}

a memória da escravidão e celebram a liberdade, com um agradecimento especial à N. S. do Rosário pela Abolição, no dia 13 de maio de 1888. É por meio desse e outros cantos e dos rituais dos ternos de Congada e Moçambique de Piedade que as histórias da escravidão e da liberdade vêm à tona no tempo presente nas Festas do Rosário em Minas Gerais.

Todas as músicas cantadas pelos congadeiros e moçambiqueiros, em sintonia com os instrumentos, revelam a dimensão simbólica dos rituais festivos. Cada verso cantado, de acordo com o timbre de voz entoado, representa e expressa a devoção aos santos cultuados e a ligação direta com o passado e a ancestralidade.

É por meio das músicas, dos rituais, das danças e da tradição oral que os saberes ancestrais são transmitidos. Uma das primeiras músicas entoadas pelo terno da Congada, no início da festança é: "Senhor padre dá licença, que eu também quero entrar. Quero ouvir a santa missa, que o senhor vai celebrar”. 8

Estes versos têm vários significados para os congadeiros, pois por cerca de sessenta anos, os ternos de Congada e Moçambique não adentravam a Igreja e não assistiam a missa. Foi a partir do ano de 1986, que os ternos começaram a participar da liturgia católica e esse canto começou a ser entoado.

De acordo com João Damasceno de Faria, pertencente à segunda geração de congadeiros - e neto do fundador José Venâncio,

\begin{abstract}
“naquela época o Congada dançava para receber água benta, não é como na época de hoje que tá evoluído, é religioso, a gente chegava no primeiro degrau embaixo da porta da igreja e não entrava dentro, o padre jogava água benta e a gente ia pra rua (...) O congado não participava da missa, não entrava na Missa, quando entrava era pra levar rei e rainha de promessa pela porta do lado, não a da frente".?
\end{abstract}

Após a missa, a música entoada pelos congadeiros é: "Demos a água benta, senhor padre. Demos a água benta! Vamos agradecer, senhor padre. Vamos agradecer!"10.

Após pedir a água benta, o grupo segue em cortejo, protegidos. Através dessas e outras músicas entoadas, a memória, a história da escravidão e dos antepassados escravos são cantadas no tempo presente.

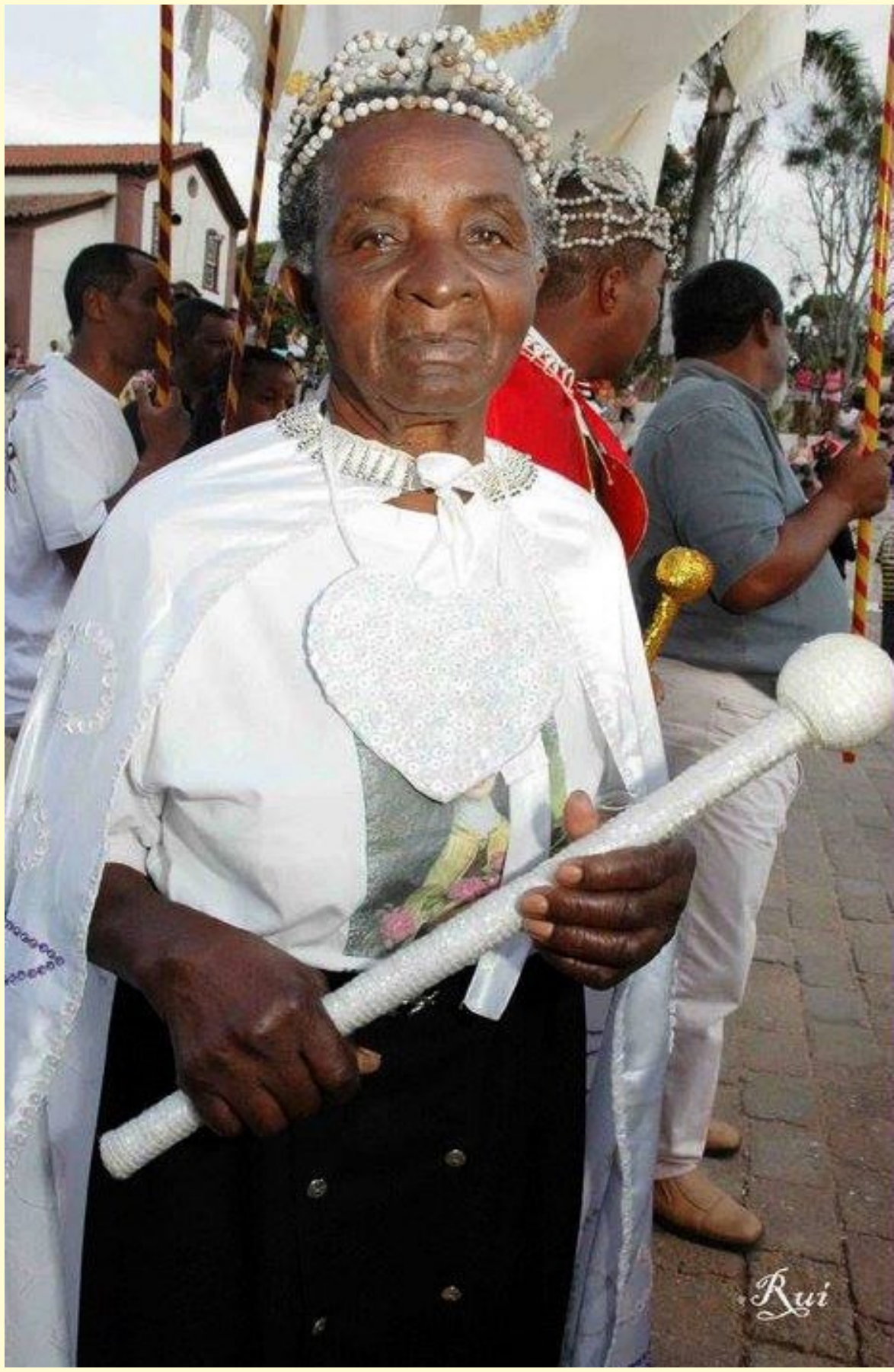

Foto 5: Dona Tereza, rainha Conga dos ternos de Congada e Moçambique de Piedade, maio de 2013. Foto Rui Ernani.

8 Canto de Congada de Piedade do Rio Grande-MG.

9 Entrevista concedida por João Damasceno de Faria, em 30 de maio de 2012.

10 Canto de Congada de Piedade do Rio Grande-MG. 
O ativismo negro dos congadeiros e moçambiqueiros está presente em suas narrativas, seus rituais, passos, danças e músicas, uma vez que reivindicam, através por meio de suas performances, espaços de cidadania e lutam contra o racismo. Em quase todas as palavras contadas dos congadeiros e moçambiqueiros, o tema sobre o racismo aparece, de alguma forma. Dona Efigênia, destaca:

(...) os brancos e ricos tinham um pouco de racismo, tirou eles de lá com todo racismo e toda riqueza mesmo com a cor branca, eles não 'teve' capacidade de tirar N. S. do Rosário da gruta, os negros, os pretos, bem pobres, 'pezinho bem rachado', foi lá e botou ela na cacunda e cantando 'vamos simbora, sua casa é sua morada' trouxe e botou ela ali e ela nunca mais saiu e tá até hoje. ${ }^{11}$

Vale destacar que as festas de Congadas no Brasil ligam-se amplamente às experiências sociais que permearam (e continuam permeando) o pós-abolição no Brasil, "territórios nos quais silêncios, esquecimentos e protestos constituíram estratégias possíveis e não excludentes, utilizadas por ex-escravos e "pessoas de cor" para se tornarem cidadãos da República e da nação" (CUNHA, 2007).

A narrativa de Maria Emerenciana da Silva, nascida em 1924, neta de escravos e filha de um dos fundadores da Sociedade de Congada e Moçambique de Piedade, sr. José Venâncio Lima, da primeira geração, revela as relações de trabalho e as sociabilidades dos descendentes de escravos e filhas do Rosário no contexto do pós-abolição (Cooper et al., 2005) em Minas Gerais. Sua voz aveludada revela algo mais.

Os cantos (da congada) são os mesmos, mas é a mesma coisa porque um dia dançava Congada, outro dia dançava maçambique, igual hoje. Agora é um pouco diferente, porque meu pai judiava mais dos meninos, porque quando era na véspera assim ele saía nas casas com as bandeiras, então pedia esmola, dançava e eles dançavam até 10 horas da noite, de casa em casa. Aí no outro dia, de manhã cedo, eles tinham que levantar porque os festeiros tinham que dar o café da manhã. ${ }^{12}$

Ouvir contar (ALBERTI, 2007) algumas dessas narrativas congadeiras e moçambiqueiras, passou, também, pelo contato com as histórias de sofrimento e dor vividas por antepassados escravos e a passagem imediata para as próprias histórias de vida, o tempo presente e as festas do Rosário. A entrevista com dona Maria Emerenciana foi feita com suas irmãs, Adalgisa Lima e Lourdes Lima Neves dos Santos. Elas construíram suas narrativas com base na memória familiar que enfatiza o sofrimento dos avôs e as histórias contadas por eles, mas que não aconteceram com seus pais, que nasceram livres. E isso só foi possível porque é a memória que faz o indivíduo, ou um grupo, experenciar o que não viveu.

A minha vó disse que ela abria lã na senzala. Não tem assim quando mata os carneiros que aproveita as lãs? Então, ela falava que ela abria lã e algodão na senzala. Os patrões dela judiava muito(...) Eu lembro que meu pai era um homem que gostava muito de fazer roça, trabalhava lá para o mato grosso, ventania, cachoeira, todas essas fazendas ele trabalhava. E ele também moía cana, fazia moagem de cana assim fora de plantação, então, ele lambicava pinga, fazia melado, rapadura, açúcar, essas coisas. (...) Eu trabalhei lá 46 anos, saí ano passado, eu fiquei com o pé muito inchado e não deu mais e as patroas foram embora, uma francesa e a outra russa.(...). ${ }^{13}$

A ética paternalista, entendida por Hebe Mattos e Ana Lugão como uma "política de domínio comum na negociação entre escravos e senhores e, depois, entre fazendeiros e colonos" (RIOS E MATTOS, 2005) estrutura as narrativas das irmãs: as relações familiares e de trabalho em que estavam envolvidas, como a íntima relação com as patroas para quem trabalharam por mais de quarenta anos em São Paulo, as relações sociais mantidas pelas irmãs com todos os membros dessas famílias e também a ênfase no tempo de serviço prestado: "Mas todas nós, todas nós aqui nunca trabalhamos em casa de um mês, dois meses. Foi sempre no mínimo cinco anos. (...) Eu trabalhei quase 60 anos para a mesma família (...) Os meus patrões, de todas, é tudo de casa. A nossa família, os patrões de São Paulo são tudo de casa." ${ }^{14}$

11 Entrevista concedida por Efigênia do Nascimento Silva em 3 de junho de 2013.

12 Entrevista concedida por Maria Emerenciana Silva, Adalgisa Lima e Lourdes Lima Neves dos Santos em 28 de maio de 2012.

13 Entrevista concedida por Maria Emerenciana Silva, Adalgisa Lima e Lourdes Lima Neves dos Santos em 28 de maio de 2012.

14 Entrevista concedida por Maria Emerenciana Silva, Adalgisa Lima e Lourdes Lima Neves dos Santos em 28 de maio de 2012. 
Por meio do depoimento oral das irmãs também foi possível compreender o quanto a memória é acionada para contar as próprias histórias de vida, marcadas pelas idas às festas do Rosário, pelos cantos, rituais e pela trajetória de serem filhas do Rosário. Ao compreender historicamente o processo de produção das narrativas congadeiras e moçambiqueiras, foi possível constatar que tal processo se faz, necessariamente, com as questões políticas e identitárias vividas no tempo presente.

Para Maurice Halbawachs, a memória individual existe sempre a partir de uma memória coletiva e as lembranças são constituídas no espaço relacional grupal que podem ser também reconstruídas ou simuladas de acordo com a percepção de outros indivíduos e da representação da memória histórica, mas nunca a memória individual está isolada (HALBAWACHS, 2004). As memórias de todos os congadeiros e moçambiqueiros entrevistados foram construídas e reconstruídas ao longo do século XX e nunca existiram isoladas, mas sempre pertenceram a uma memória que se iniciou no processo pós-emancipacionista e passou por inúmeras transformações, porém, essas memórias "prosseguiram seu trabalho de subversão no silêncio e de maneira quase imperceptível.” (POLLACK, 1989).

Pollack considera que a memória é uma operação coletiva dos acontecimentos e das interpretações do passado que se quer salvaguardar, que integra tentativas conscientes ou não de definir e de reforçar sentimentos de pertencimento e fronteiras sociais entre coletividade: partidos, sindicatos, igrejas, aldeias, regiões, famílias etc. A referência ao passado serve para manter a coesão dos grupos, para definir seu lugar, sua complementaridade. Pollack cita Henry Rousso e afirma que ao invés de usar a “memória coletiva”, é adequado falar em memória enquadrada e em trabalho de enquadramento da memória. (POLLACK, 1989).

E desse debate, é interessante pensarmos em algumas questões: como a memória de dona Efigênia, Emerenciana, Adalgiza, Lourdes, João Damasceno, Carlos Antônio e tantos outros congadeiros e moçambiqueiros foi sendo atualizada? Como elas foram sendo constituídas? Para Michael Pollak, os elementos constitutivos da memória são os acontecimentos vividos pessoalmente ou 'por tabela', uma espécie de memória herdada e é a memória um dos elementos constituintes da identidade, desse modo, para haver identidade tem que haver o enquadramento da memória. E a memória subterrânea? Mesmo sendo subterrânea, há sua construção e sua politização, só não há visibilidade - como é o caso das memórias dos congadeiros e moçambiqueiros.

A possibilidade de perceber as mudanças e as continuidades nas práticas culturais congadeiras e moçambiqueiras está sendo possível com a análise dos relatos, das experiências sociais e das memórias das três gerações, pois ela foi deixada como um rastro no decorrer desses anos.

A Congada e Moçambique de Piedade do Rio Grande rompe com o silêncio, ao som da sanfona, da caixa e dos guizos e vem se transformando em patrimônio cultural, revelando orgulho pelo passado e pela ancestralidade, "as metamorfoses sociais possíveis a tais atores estiveram, entretanto, firmemente ancoradas na associação entre identidade negra e memória do cativeiro, seja como reminiscência familiar, estigma ou expressão festiva e cultural" (ABREU, 2011).

Há uma relação entre a memória da escravidão e a valorização da Congada e Moçambique no tempo presente. Essa prática cultural passa por um processo de transformação, tornando-se um patrimônio cultural herdado e reconstruído por descendentes de escravos. Nesse sentido, apropriando desse contexto, os congadeiros e moçambiqueiros reafirmam politicamente suas trajetórias históricas e ganham, cada vez mais, visibilidade e novas perspectivas enquanto grupo cultural.

Desse modo, há também uma percepção da história, memória e tradição oral do grupo enquanto patrimônios, "que precisam ser valorizados, lembrados e, desta forma, reparados". (ABREU, 2007) e essa questão remete-se também ao direito à reparação e ao dever de memória.

A tradição oral, transmitida de geração em geração, constitui uma das mais importantes bases da identidade negra em Piedade do Rio Grande. Contar histórias da ancestralidade negra faz parte de uma estratégia dos mais antigos da comunidade, para que o passado permaneça no presente. 


\section{Referências bibliográficas:}

ABREU, M. C. 2007. Cultura imaterial e patrimônio histórico nacional. In: ABREU, M. C. SOIHET, R. (org.), Cultura política e leituras do passado. Historiografia e ensino de História. Rio de Janeiro: Nova Fronteira/ Faperj. p. 25-48.

2011. Remanescentes das comunidades dos Quilombos: memória do cativeiro, patrimônio cultural e direito à reparação. In: Simpósio Nacional de História - ANPUH, XXVI, São Paulo, 2011. Anais do XXVI Simpósio Nacional de História-ANPUH. 1-17.

ALBERTI, V.. 2007. Ouvir Contar. Textos em História Oral. Rio de Janeiro, FGV Editora, 196p.

BÉDARIDA, F. 2008. Tempo presente e presença da história. In: AMADO, J. e FERREIRA, M. M. (org.), Usos e abusos da história oral. 8 ed. Rio de Janeiro: Editora FGV, 219-299.

BRASILEIRO, J. 2010. Cultura afro-brasileira na escola: o congado na sala de aula. São Paulo: Ícone, 98p.

COOPER, F. HOLT, T. C., SCOTT, R. 2005. Além da escravidão: investigações sobre raça, trabalho e cidadania em sociedades pós-emancipação. Rio de Janeiro: Civilização Brasileira, 2005. 346p.

COSTA, P. T. M. 2006. As raízes da Congada: a renovação do presente pelos filhos do rosário. Brasília, DF. Tese de doutorado. Universidade de Brasília. Brasília, 241p.

CUNHA, O. G. GOMES, F. S. (org.). 2007. Quase-cidadãos: histórias e antropologias da pós-emancipação no Brasil. Rio de Janeiro: Editora FGV, 452p.

FERREIRA, M. M. e AMADO, J. (org.). 2006. Usos e abusos da história oral. 8 ed. Rio de Janeiro: Editora FGV, 304p.

História oral: velhas questões, novos desafios. In: CARDOSO, C. F. e VAINFAS, R. (org.). 2011. Novos Domínios da História. Rio de Janeiro: Objetiva, 546p.

GILROY, P. 2001. O Atlântico Negro. Modernidade e dupla consciência. São Paulo, Rio de Janeiro, 34/ Universidade Cândido Mendes - Centro de Estudos Afro-Asiáticos, 345p.

HALBWACHS, M. 2004. A memória coletiva. São Paulo: Ed. Centauro, 322p.

KIDDY, E. 2005. blacks of the Rosary: memory and history in Minas Gerais, Brazil. PennsylvanisState: University Press, 2005. 456p.

MARTINS, L. M. 1997. Afrografias da Memória: o reinado do Rosário no Jatobá. São Paulo: Perspectiva; Belo Horizonte: Mazza Edições,223p.

MATTOS, H. 2013. Das cores do silêncio: os significados da liberdade no sudeste escravista (Brasil, século XIX). 3 ed. Campinas, SP: Editora da Unicamp,381p.

POLLACK, M. 1989. “Memória, esquecimento e silêncio”. Estudos Históricos, vol. 2, n.3, 1989. p. 3-15. 1992. Memória e Identidade Social. Estudos Históricos, Rio de Janeiro, vol. 5, n. 10.

RIOS, A. L. 2004. O pós-abolição como problema histórico: balanços e perspectivas. Topoi (Rio de Janeiro), Rio de Janeiro, v. 5, n. 8, p. 170-198.

MATTOS, H. 2005. Memórias do cativeiro: família, trabalho e cidadania no pós-abolição. Rio de Janeiro: Civilização Brasileira, 301p.

SLENES, R. W. 2007. "Eu venho de muito longe, eu venho cavando": jongueiros cumba na senzala centro-africana. In: LARA, S. H. e PACHECO, G. (org.). Memória do Jongo. As gravações históricas de Stanley Stein, Vassouras, 1949. Rio de Janeiro: Folha Seca/Campinas: Cecult.

SIRINELLI. J. 2006. A geração. In: AMADO, J. e FERREIRA, M. M. (org.), Usos e abusos da história oral. 8 ed. Rio de Janeiro: Editora FGV, 131-137. 


\section{Artigos}

SOUZA, M. M. 2001. Reis negros no Brasil escravista: história da festa de coroação do rei congo. Belo Horizonte: Ed. UFMG, 234p. 